\title{
Bacillus saliphilus sp. nov., isolated from a mineral pool in Campania, Italy
}

\author{
Ida Romano, Licia Lama, Barbara Nicolaus, Agata Gambacorta \\ and Assunta Giordano
}

Correspondence

Assunta Giordano

agiordano@icmib.na.cnr.it

\author{
Istituto di Chimica Biomolecolare, Comprensorio ex Olivetti, via Campi Flegrei 34, 80078 \\ Pozzuoli, Na, Italy
}

\begin{abstract}
A haloalkaliphilic Gram-positive bacterium, strain $6 \mathrm{AG}^{\top}$, that grew aerobically at an optimum temperature of $37{ }^{\circ} \mathrm{C}$ and at $\mathrm{pH}$ 7-10 (optimum 9.0), was isolated from algal mat from a mineral pool located in Malvizza in the Campania region (southern Italy). The isolate tolerated high concentrations of $\mathrm{NaCl}$, up to $25 \%$. On the basis of $16 \mathrm{~S}$ rRNA gene sequence similarity, the strain was shown to belong to the genus Bacillus. Analysis of the 16S rRNA gene sequence revealed high similarity between strain $6 \mathrm{AG}^{\top}$ and an unidentified isolate from Hailaer soda lake (China) (99.9\% identity) and two Kenyan isolates, 3E1 and WE4 (98.3 and $97.8 \%$ identity, respectively). The $\mathrm{G}+\mathrm{C}$ content of the DNA was $48 \cdot 4 \mathrm{~mol} \%$. The predominant respiratory quinones were MK-7 $\left(\mathrm{H}_{2}\right), \mathrm{MK}-7\left(\mathrm{H}_{4}\right)$ and DMK-7 $\left(\mathrm{H}_{2}\right)$; phosphatidylglycerol and diphosphatidylglycerol were the predominant polar lipids. iC15:0 and aiC15:0 were the major fatty acids. Strain $6 \mathrm{AG}^{\top}$ accumulated osmolytes. The phylogenetic distance of strain $6 \mathrm{AG}^{\top}$ (=DSM $15402^{\top}=$ ATCC BAA $-957^{\top}$ ) from any recognized species within the genus Bacillus allowed it to be classified as the type strain of Bacillus saliphilus sp. nov.
\end{abstract}

The Campania region (Italy) is rich in mineral environments but they have not been explored in any detail regarding their microbial communities. This research was aimed at the screening, isolation and identification of halophilic, alkaliphilic and haloalkaliphilic micro-organisms from the local ecosystems in Campania, Italy. Recently we have isolated, from a hydrothermal site in Campania, a novel haloalkaliphilic species classified as Planococcus rifietoensis, able to hydrolyse 5-bromo-4-chloro-3-indoyl $\beta$-D-glucopyranoside (XGlc) (Romano et al., 2003). In 1985, the isolation of an obligately alkaliphilic, extremely halotolerant Bacillus strain, WN13, was described, later classified by Fritze (1996) as Bacillus haloalkaliphilus. Little effort has been devoted to the study of intracellular ion concentrations in halophilic Gram-positive bacteria. Apparent intracellular cation concentrations as high as those present in the growth medium were reported in Bacillus haloalkaliphilus (Weisser \& Trüper, 1985). However, this species is now known to produce ectoine as the main osmotic solute (Oren, 2002). Few Bacillus species that grow in the presence of high $\mathrm{NaCl}$ concentrations and are also alkaliphilic have been described (Fritze, 1996; Arahal \& Ventosa, 2002). The significance of haloalkaliphiles has prompted the isolation

Published online ahead of print on 30 July 2004 as DOI 10.1099/ ijs.0.63298-0.

The GenBank/EMBL/DDBJ accession number for the 16S rRNA gene sequence of strain $6 \mathrm{AG}^{\top}$ is $\mathrm{AJ} 493660$. and characterization of such strains from a variety of environments.

In this study, a new member of the genus Bacillus is proposed on the basis of polyphasic studies. Strain $6 \mathrm{AG}^{\mathrm{T}}$ was isolated from a mat of green algae collected from a mineral pool at the Malvizza site (Montecalvo Irpino, Avellino province, Campania region, south Italy). The strain was isolated by the dilution-plating technique from the algal mat ( $\mathrm{pH} 8 \cdot 0,18^{\circ} \mathrm{C}$ ) at the green-red algae boundary in a small pool. Enrichment medium (medium 1) contained the following components $\left(1^{-1}\right): \mathrm{Na}_{2} \mathrm{CO}_{3}, 3 \cdot 0 \mathrm{~g} ; \mathrm{KCl}, 2 \cdot 0 \mathrm{~g}$; $\mathrm{MgSO}_{4} .7 \mathrm{H}_{2} \mathrm{O}, 1.0 \mathrm{~g} ; \mathrm{NaCl}, 160 \mathrm{~g}$, trisodium citrate, $3.0 \mathrm{~g}$; yeast extract, $10 \cdot 0 ; \mathrm{MnCl}_{2} \cdot 4 \mathrm{H}_{2} \mathrm{O}, 0.36 \mathrm{mg} ; \mathrm{FeSO}_{4}, 50 \mathrm{mg}$. $\mathrm{Na}_{2} \mathrm{CO}_{3}$ and $\mathrm{NaCl}$ were autoclaved separately. The $\mathrm{pH}$ of medium 1 was $9 \cdot 0$. Growth on single carbon sources at $10 \mathrm{~g} \mathrm{l}^{-1}$ was tested on liquid medium (medium 2) containing $\left(\mathrm{g} \mathrm{l}^{-1}\right) \mathrm{K}_{2} \mathrm{HPO}_{4}, 7 \cdot 0 ; \mathrm{KH}_{2} \mathrm{PO}_{4}, 2 \cdot 0 ; \mathrm{MgSO}_{4} .7 \mathrm{H}_{2} \mathrm{O}$, $0 \cdot 1 ;\left(\mathrm{NH}_{4}\right)_{2} \mathrm{SO}_{4}, 1 \cdot 0 ; \mathrm{NaCl}, 160 ; \mathrm{Na}_{2} \mathrm{CO}_{3}, 3 \cdot 0$; with $500 \mu \mathrm{l}$ thiamine hydrochloride solution $\mathrm{l}^{-1}\left(100 \mathrm{mg} \mathrm{l}^{-1}\right)$. Solid media were prepared by the addition of $1 \cdot 8 \%$ agar.

Cell morphology was determined by phase-contrast microscopy (Zeiss). Colony morphology was analysed on solid medium with a Leica M8 stereomicroscope. Tolerance of $\mathrm{NaCl}$ and growth at various temperatures and $\mathrm{pH}$ was assessed in medium 1. All growth tests were done at the optimal growth temperature for 3 days. Sensitivity of the strain to antibiotics was tested by using medium 1 with agar 
$(1 \cdot 8 \%)$ and Sensi discs (6 mm; Oxoid); tests were incubated for $48 \mathrm{~h}$. Antibiotic tests were carried out according to Romano et al. (1993). Casein and gelatin hydrolysis, oxidase, tyrosinase, aminopeptidase (Bactident-Merck) and catalase were tested in medium 1 . For nitrate reduction, medium 1 plus $0 \cdot 1 \% \mathrm{KNO}_{3}$ was employed. Hydrolysis of hippurate was assessed in medium 1 plus hippurate $(1 \%)$ (Romano et al., 1996). Gram-staining was performed according to Dussault (1955). The KOH test was performed according to Halebian et al. (1981). Hydrolysis of $N^{\prime}$-benzoyl-arginine $p$-nitroaniline (BAPNA) stereoisomers was tested according to Oren \& Galinski (1994). The extraction of intracellular solutes, their purification and quantification were done according to Romano et al. (2001).

Cell mass for quinone and lipid analysis was obtained from culture in medium 1 at $37^{\circ} \mathrm{C}$ at $\mathrm{pH} 9 \cdot 0$ at optimal $\mathrm{NaCl}$ concentration. Lipid analysis was performed as reported by Romano et al. (2001). Lipid hydrolysis and identification of fatty acid methyl esters were done as reported by Romano et al. (2001). Quinones were analysed by LC/MS on a reverse-phase column, by EI/MS and $\mathrm{H}^{1}$ NMR spectra.

The $\mathrm{G}+\mathrm{C}$ content was determined by the method of Tamaoka \& Komagata (1984). DNA was hydrolysed and the resultant nucleotides were analysed by HPLC. The DNA was isolated as described previously (Romano et al., 2003).

The total 16S rRNA gene sequence was determined by direct sequencing of the PCR product. Genomic DNA extraction, amplification of the 16S rRNA gene and purification of PCR products were carried out as described previously (Romano et al., 2003). Purified PCR products were sequenced by the DSMZ using the ABI PRISM Dye Terminator cycle sequencing ready reaction kit (Applied Biosystems) as directed in the manufacturer's protocol. Sequence reactions were electrophoresed using an Applied Biosystems 373A DNA sequencer.

The multiple sequence alignment program CLUSTAL $\mathrm{W}$ (Chenna et al., 2003) was used to align the 16S rRNA gene sequence of our isolate with the sequences of representative organisms belonging to the Bacillus/Staphylococcus group. Sequences of 16S rRNA genes for comparison were obtained from the EMBL database or RDP. Phylogenetic analysis was performed using the PHYLIP package, version 3.5 (Felsenstein, 1993). Distances (distance options according to Kimura's two-parameter model) and clustering with the maximum-parsimony method were determined by using bootstrap values based on 1000 replications.

$16 \mathrm{~S}$ rRNA gene phylogenetic analysis based on the neighbour-joining method (Saitou \& Nei, 1987) showed strain $6 \mathrm{AG}^{\mathrm{T}}$ to be placed in the genus Bacillus (Fig. 1). In particular, the sequence similarity to any other species within the genus Bacillus with validly published names was less than $95 \cdot 7 \%$.

$16 \mathrm{~S}$ rRNA gene sequencing of strain $6 \mathrm{AG}^{\mathrm{T}}$ showed $99 \cdot 9 \%$ similarity to an unidentified and not described isolate from Hailaer soda lake (China) named strain T1 (AF275706). Further, two undescribed isolates, strains 3E1 (X92162) and WE4 (X92161), isolated from Lake Elementeita in the Kenyan section of the East African Rift Valley, showed similarity greater than $97 \%$. The Kenyan isolates were related to but distinct from Bacillus agaradhaerens and Bacillus clarkii (Duckworth et al., 1996; Nielsen et al., 1995),

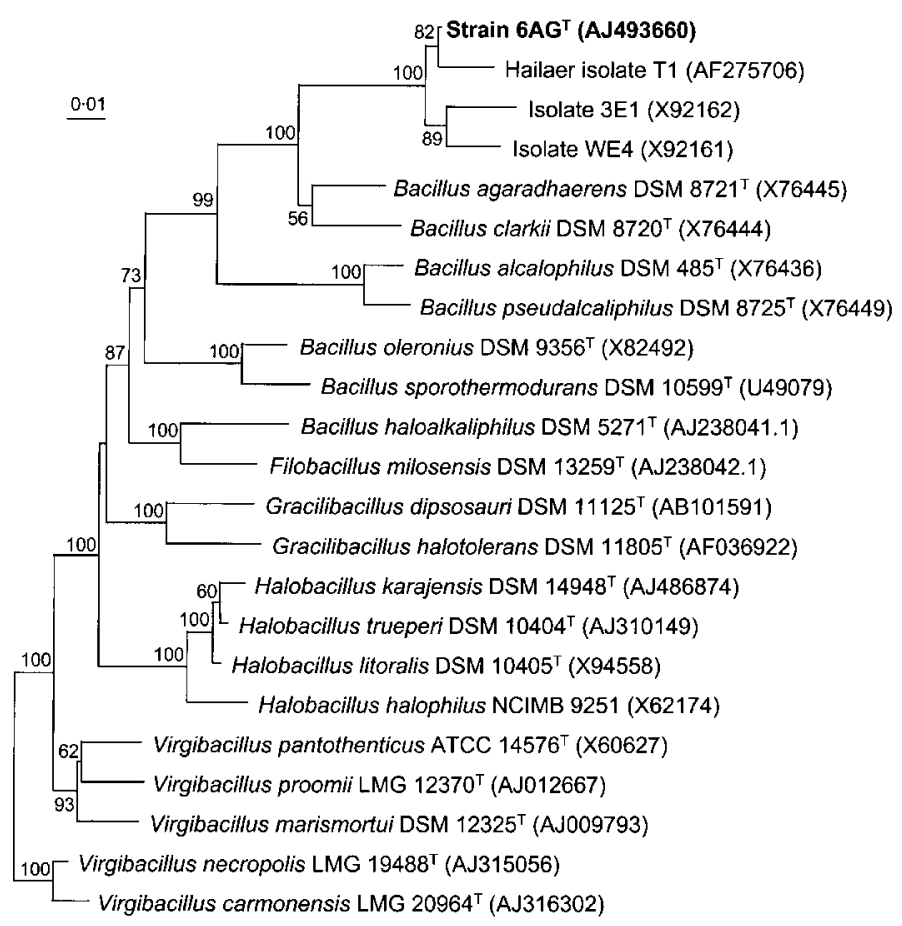

Fig. 1. Phylogenetic tree showing the position of strain $6 \mathrm{AG}^{\top}$ among related bacteria of the genus Bacillus and related genera. The tree was obtained using the neighbourjoining method. Numbers at branching points are bootstrap percentages, based on 1000 resamplings. Bar, 0.01 substitutions per nucleotide position. 
while our isolate showed less than 96 and $95 \%$ similarity, respectively, to these two latter species. Phylogenetic analysis based on the neighbour-joining and maximum-parsimony methods showed the same position for strain $6 \mathrm{AG}^{\mathrm{T}}$ and the three undescribed isolates among the genus Bacillus, grouping together and forming a cluster separated from other species (Fig. 1). The $\mathrm{G}+\mathrm{C}$ content of the DNA of strain $6 \mathrm{AG}^{\mathrm{T}}$ was $48 \cdot 4 \mathrm{~mol} \%$.

Strain $6 \mathrm{AG}^{\mathrm{T}}$ was a Gram-positive non-sporulating coccus measuring $0 \cdot 8-0.9 \mu \mathrm{m}$. It grew as single cells and/or clusters and was non-sporulating, even in the presence of $100 \mathrm{mg}$ $\mathrm{MnCl}_{2} \mathrm{ml}^{-1}$. Colonies on enrichment medium 1 were usually yellow. The main features of the novel isolate are listed in Table 1.
The isolate required aerobic conditions for growth. It grew in medium 1 containing up to $25 \% \mathrm{NaCl}$ and did not grow in the absence of salts. The optimum $\mathrm{NaCl}$ concentration in the medium was $16 \%$. Strain $6 A^{T}{ }^{T}$ did not have a specific requirement for the $\mathrm{Na}^{+}$ion, as it also grew in the presence of $\mathrm{KCl}$. The optimal temperature for growth was $37^{\circ} \mathrm{C}$ and the temperature range was $4-50{ }^{\circ} \mathrm{C}$. The optimal $\mathrm{pH}$ for growth was $9 \cdot 0$ and the $\mathrm{pH}$ range was 7-10 (Table 1). Strain $6 \mathrm{AG}^{\mathrm{T}}$ was able to grow on medium 2 containing glucose. Other carbon sources did not sustain growth. Among the antibiotics tested, strain $6 \mathrm{AG}^{\mathrm{T}}$ was sensitive to $(\mu \mathrm{g})$ vancomycin (30), ampicillin (25), novobiocin (30), fusidic acid (10), streptomycin (25), chloramphenicol (10), erythromycin (5 and 30) and bacitracin (10).

Table 1. Phenotypic properties of strain $6 \mathrm{AG}^{\top}$, B. agaradhaerens and B. clarkii

Data for reference taxa were taken from Nielsen et al. (1995). +, Positive or present; -, negative or absent; NR, not reported; W, weak reaction. All three strains are negative for starch hydrolysis.

\begin{tabular}{|c|c|c|c|}
\hline Property & $6 \mathrm{AG}^{\mathrm{T}}$ & $\begin{array}{l}\text { B. agaradhaerens } \\
\text { DSM } 8721^{\mathrm{T}}\end{array}$ & $\begin{array}{c}\text { B. clarkii } \\
\text { DSM } 8720^{\mathrm{T}}\end{array}$ \\
\hline Sampling site & Algal mat & Soil & Soil \\
\hline Colony colour & Yellow & $\begin{array}{l}\text { White and rhizoid with } \\
\text { filamentous margin }\end{array}$ & $\begin{array}{c}\text { Cream-white to } \\
\text { dark yellow }\end{array}$ \\
\hline Gram reaction & + & NR & + \\
\hline Oxidase & + & NR & NR \\
\hline Catalase & $\mathrm{W}$ & NR & NR \\
\hline \multicolumn{4}{|l|}{ Hydrolysis of: } \\
\hline Gelatin & + & - & + \\
\hline Phenylalanine deamination & - & - & $\mathrm{NR}$ \\
\hline \multicolumn{4}{|c|}{$\mathrm{NaCl}$ concentration for growth $(\% \mathrm{w} / \mathrm{v})$ : } \\
\hline Minimum & $>0$ & $0 \cdot 5$ & $0 \cdot 5$ \\
\hline Optimum & 16 & NR & NR \\
\hline Maximum & 25 & 16 & 16 \\
\hline Growth with $\mathrm{KCl}$ & + & NR & NR \\
\hline \multicolumn{4}{|l|}{ Growth temperature $\left({ }^{\circ} \mathrm{C}\right)$ : } \\
\hline Range & $4-50$ & $10-45$ & $15-45$ \\
\hline Optimum & 37 & 30 & 30 \\
\hline \multicolumn{4}{|l|}{ pH for growth: } \\
\hline Range & $7-10$ & $>7 \cdot 0$ & $>7 \cdot 0$ \\
\hline
\end{tabular}


The phenotypic features of strain $6 \mathrm{AG}^{\mathrm{T}}$ and B. agaradhaerens and $B$. clarkii differ in several aspects (Table 1). Strain $6 \mathrm{AG}^{\mathrm{T}}$ is a regular non-sporulating coccus, while $B$. agaradhaerens and B. clarkii are sporulating rods. The most interesting common feature between the above-mentioned Bacillus species and strain $6 \mathrm{AG}^{\mathrm{T}}$ is their haloalkaliphilicity; in fact, they grew well at high $\mathrm{pH}$ values and in the presence of $\mathrm{NaCl}$ and they were able to tolerate $\mathrm{NaCl}$ concentrations up to $16-25 \%$. Carbohydrate utilization profiles showed growth on glucose for $6 \mathrm{AG}^{\mathrm{T}}$ and on several sources for $B$. agaradhaerens, while no growth was observed in minimal carbohydrate media for B. clarkii (Nielsen et al., 1995).

Strain $6 \mathrm{AG}^{\mathrm{T}}$ possessed complex lipids based on fatty acids. The total lipid content accounted for $9-11 \%$ of the total dry weight of cells grown under optimal growth conditions in medium 1. Under these conditions, phosphoethanolamine, diphosphatidylglycerol and phosphatidylglycerol were the main lipids (approx. 96\%), identified by ${ }^{1} \mathrm{H}$ and ${ }^{13} \mathrm{C}$ NMR spectra. The chemical shift values of signals present in spectra were similar to those reported by Romano et al. (2001), with the exception of the absence of the signals due to double bonds in the fatty acid chains. The assignments were done by comparison with commercial standards and by distortionless enhanced polarization transfer (DEPT) experiments. Glycolipids were not visualized; this was probably due to their absence or occurrence in very small amounts.

The fatty acid composition determined from cells grown under standard growth conditions was characterized by the abundance of branched saturated acyl chains; in particular, aiC $15: 0$ reached $89 \%$ of total fatty acid methyl esters.

LC/MS as well as EI/MS analyses of the quinone content of strain $6 \mathrm{AG}^{\mathrm{T}}$ showed three major peaks, assigned to MK-7 $\left(\mathrm{H}_{4}\right)$, MK-7 $\left(\mathrm{H}_{2}\right)$ and demethylated MK-7 $\left(\mathrm{H}_{2}\right)$ [DMK$\left.7\left(\mathrm{H}_{2}\right)\right]$ in a relative ratio of $1 \cdot 5: 7 \cdot 0: 1 \cdot 5$.

Little effort has been devoted to the study of osmoprotectants accumulated by halophilic Gram-positive bacteria; under optimal growth conditions, strain $6 \mathrm{AG}^{\mathrm{T}}$ accumulated glycine betaine, hydroxyectoine, ectoine and glutamate.

On the basis of these results, we suggest that strain $6 \mathrm{AG}^{\mathrm{T}}$ represents a novel species, Bacillus saliphilus sp. nov. This affiliation is preliminary, in that the creation of a new genus based on a single strain makes it impossible to assess the limits of variability of the taxon. Finally, it is well known that the genus Bacillus is clearly heterogeneous, and many contributions have been made to the development of Bacillus systematics (Berkeley et al., 2002).

\section{Description of Bacillus saliphilus sp. nov.}

Bacillus saliphilus (sal.i.phi'lus. L. n. sal salt; Gr. adj. philos loving; N.L. masc. adj. saliphilus loving salt).

Alkalitolerant and halotolerant. Cells are Gram-positive, regular cocci, $0 \cdot 8-0 \cdot 9 \mu \mathrm{m}$ in diameter, appearing singly and/or in clumps. Colonies are yellow. Mesophilic, exhibiting optimum growth at $37^{\circ} \mathrm{C}$, but is able to grow between 4 and $50^{\circ} \mathrm{C}$ and at $\mathrm{pH} 7 \cdot 0-10 \cdot 0$ (optimum $\mathrm{pH} 9 \cdot 0$ ). Grows at salinity of $1-25 \%(\mathrm{w} / \mathrm{v})$, with optimum growth at $16 \%$ $(\mathrm{w} / \mathrm{v})$ salts. Able to grow on glucose as a sole carbon source. Positive for oxidase, gelatinase, tyrosine decomposition and nitrate reduction but negative with respect to starch, casein, hippurate and phenylalanine hydrolysis. Catalase reaction is weak. Possesses $\alpha$-glucosidase activity. Menaquinones are MK- $7\left(\mathrm{H}_{2}\right)(70 \%), \mathrm{MK}-7\left(\mathrm{H}_{4}\right)(15 \%)$ and DMK-7 $\left(\mathrm{H}_{2}\right)$ $(15 \%)$ and the predominant polar lipids are phosphatidylglycerol and diphosphatidylglycerol. iC15:0, aiC15:0 $(89 \%)$ and $\mathrm{C} 17: 0$ are the main cellular fatty acids. Accumulates glycine betaine as the major osmoprotectant and hydroxyectoine, ectoine and glutamate as minor components. The $\mathrm{G}+\mathrm{C}$ content of DNA is $48.4 \mathrm{~mol} \%$. Phylogenetically related to three uncharacterized microorganisms and to B. agaradhaerens ( $95.4 \%$ similarity) on the basis of $16 \mathrm{~S}$ rRNA gene sequences. The following antibiotics inhibit growth ( $\mu \mathrm{g}$ unless stated): chloramphenicol (10), erythromycin $(5,30)$, bacitracin (10), vancomycin (30), ampicillin (25), fusidic acid (10), streptomycin (25) and novobiocin (30). Grows in the presence of penicillin $\mathrm{G}(2,10 \mathrm{IU})$, tetracycline $(30,50)$, kanamycin (30), neomycin (30) and gentamicin (30).

The type strain, strain $6 \mathrm{AG}^{\mathrm{T}}\left(=\mathrm{DSM} 15402^{\mathrm{T}}=\right.$ ATCC BAA$957^{\mathrm{T}}$ ), was isolated from an algal mat around a small, bubbling mineral pool at the Malvizza site (Campania, Italy).

\section{Acknowledgements}

The authors thank V. Calandrelli, E. Esposito and E. Pagnotta for technical assistance, A. Maiello, V. Mirra and S. Zambardino of NMR-ICB service for NMR spectra and O. De Luca for GC/MS spectra. This project was partially supported by PNRA and Regione Campania.

\section{References}

Arahal, D. R. \& Ventosa, A. (2002). Moderately halophilic and halotolerant species of Bacillus and related genera. In Applications and Systematics of Bacillus and Relatives, pp. 83-99. Edited by R. C. W. Berkeley, M. Heyndrickx, N. Logan \& P. De Vos. Oxford: Blackwell.

Berkeley, R. C. W., Heyndrickx, M., Logan, N. \& De Vos, P. (editors) (2002). Applications and Systematics of Bacillus and Relatives. Oxford: Blackwell.

Chenna, R., Sugawara, H., Koike, T., Lopez, R., Gibson, T. J., Higgins, D. G. \& Thompson, J. D. (2003). Multiple sequence alignment with the CLUSTAL series of programs. Nucleic Acids Res 31, 3497-3500.

Duckworth, A. W., Grant, W. D., Jones, B. E. \& van Steenbergen, R. (1996). Phylogenetic diversity of soda lake alkaliphiles. FEMS Microbiol Ecol 19, 181-191.

Dussault, H. P. (1955). An improved technique for staining red halophilic bacteria. J Bacteriol 70, 484-485. 
Felsenstein, J. (1993). PHYLIP (phylogeny inference package), version 3.5c. Distributed by the author. Department of Genetics, University of Washington, Seattle, USA.

Fritze, D. (1996). Bacillus haloalkaliphilus sp. nov. Int J Syst Bacteriol 46, 98-101.

Halebian, S., Harris, B., Finegold, S. M. \& Rolfe, R. D. (1981). Rapid method that aids in distinguishing Gram-positive from Gramnegative anaerobic bacteria. J Clin Microbiol 13, 444-448.

Nielsen, P., Fritze, D. \& Priest, F. G. (1995). Phenetic diversity of alkaliphilic Bacillus strains: proposal for nine new species. Microbiology 141, 1745-1761.

Oren, A. (2002). Halophilic Microorganisms and Their Environments. Boston: Kluwer Academic.

Oren, A. \& Galinski, E. A. (1994). Hydrolysis of $\mathrm{N}^{\prime}$-benzoylarginine- $p$-nitroanilide stereoisomers as a phenotypic test: a study of Gram-positive halotolerant bacteria. Syst Appl Microbiol 17, 7-10.

Romano, I., Manca, M. C., Lama, L., Nicolaus, B. \& Gambacorta, A. (1993). A method for antibiotic assay on Sulfolobales. Biotechnol Tech 7, 439-440.
Romano, I., Nicolaus, B., Lama, L., Manca, M. C. \& Gambacorta, A. (1996). Characterization of a haloalkaliphilic strictly aerobic bacterium, isolated from Pantelleria Island. Syst Appl Microbiol 19, 326-333.

Romano, I., Nicolaus, B., Lama, L., Trabasso, D., Caracciolo, G. \& Gambacorta, A. (2001). Accumulation of osmoprotectants and lipid pattern modulation in response to growth conditions by Halomonas pantelleriense. Syst Appl Microbiol 24, 342-352.

Romano, I., Giordano, A., Lama, L., Nicolaus, B. \& Gambacorta, A. (2003). Planococcus rifietensis sp. nov, isolated from algal mat collected from a sulfurous spring in Campania (Italy). Syst Appl Microbiol 26, 357-366.

Saitou, N. \& Nei, M. (1987). The neighbor-joining method: a new method for reconstructing phylogenetic trees. Mol Biol Evol 4, 406425.

Tamaoka, J. \& Komagata, K. (1984). Determination of DNA base composition by reversed-phase high-performance liquid chromatography. FEMS Microbiol Lett 25, 125-128.

Weisser, J. \& Trüper, H. G. (1985). Osmoregulation in a new haloalkaliphilic Bacillus from the Wadi Natrun (Egypt). Syst Appl Microbiol 6, 7-11. 